\title{
Atribuição e negociação de identidades em festas BDSM no Rio de Janeiro
}

\author{
Marília Loschi de Melo*
}

Resumo: $O$ BDSM é um conjunto de práticas e representações constantemente referido ao universo do sadomasoquismo e do fetichismo. O objetivo geral de minha dissertação de mestrado é produzir uma etnografia sobre festas BDSM no Rio de Janeiro, onde os frequentadores se reúnem para praticar o fetichismo e o sadomasoquismo, sendo que a festa também é aberta a nãopraticantes, que podem simplesmente observar. No presente trabalho, exponho brevemente meu percurso metodológico e introduzo uma discussão sobre identidade. A intenção é refletir sobre os processos de atribuição e negociação de identidades no meio BDSM, tendo como ponto de partida três categorias identitárias encontradas no campo: "dominadores", "submissos" e "switchers" (que ora atuam como "dominadores", ora como "submissos"). O material etnográfico que utilizo vem da observação participante em três festas sadomasoquistas diferentes, além de conversas no próprio espaço da festa e pela Internet (com pessoas que conheci nas festas).

Palavras-Chave: Sadomasoquismo; Fetichismo; festa BDSM; identidade

Abstract: BDSM is a set of practices and representations usually referring to the practices known as sadomasochism and fetishism. My dissertation consists of an ethnography about BDSM parties in Rio de Janeiro in which people get together for fetish and sadomasochism plays or just to watch others play, as long as these parties are open to public in general and allow non-practitioners in. In this present work, I briefly describe my methodological path and present a discussion on identity. My intent is to think about the process of attribution and negotiation of identities in the BDSM scene, based on three identity categories found on fieldwork: "dominant", "submissive" and "switchers". The Ethnography was made on three different BDSM parties, and my data also include online conversations with some of my so-called informants- people I met at those parties.

Keywords: Sadomasoquism; Fetichism; BDSM party; identity

\footnotetext{
* Marília Loschi de Melo é mestranda do Programa de Pós-Graduação em Ciências Sociais da Universidade do Estado do Rio de Janeiro (PPCIS/UERJ).
}

INTRATEXTOS, Rio de Janeiro, Número Especial 01, pp.65-84, 2010 


\section{Introdução}

O BDSM é um conjunto de práticas e representações constantemente referido ao universo do sadomasoquismo e do fetichismo. Embora não sejam a mesma coisa, sadomasoquismo e fetichismo caminham muito próximos nos discursos sobre sexualidade.

O objetivo geral de minha dissertação de mestrado é produzir uma etnografia sobre festas BDSM no Rio de Janeiro, onde os frequentadores se reúnem para praticar o fetichismo e o sadomasoquismo, sendo que a festa também é aberta a não-praticantes, que podem simplesmente observar.

Neste artigo, meu objetivo é refletir sobre os processos de atribuição e negociação de identidades no meio BDSM, tendo como ponto de partida quatro categorias identitárias encontradas no campo: "dominadores", "submissos", "podólatras" e "switchers" (que ora atuam como "dominadores", ora como "submissos") e sua relação com o mundo "baunilha" (dos não-praticantes). O material etnográfico com o qual trabalharei vem da observação participante em três festas sadomasoquistas diferentes, além de conversas pela Internet com as pessoas que conheci nas festas.

Explicações cuidadosas dos praticantes nas festas e nas didáticas páginas sobre sadomasoquismo na Internet apontam para uma relação de poder com dois eixos: de um lado, alguém que domina, e de outro, alguém dominado. Em algum ponto entre os dois extremos transitam as práticas fetichistas, uma vez que costumam ser colocadas em cena dentro de uma relação também de dominação/submissão.

Esse discurso geral que define e orienta as práticas do BDSM também é responsável pela definição e orientação de "tipos ideais", pregnantes de atribuição de identidade. A partir desse modelo ideal, o sadomasoquista é a pessoa que tem prazer na dor, podendo ser um sádico - cujo prazer é infligir dor física ou psicológica - ou um masoquista - cujo prazer é receber os maus tratos. Já o fetichista é a pessoa que, para sentir prazer, não prescinde de determinado objeto, o objeto-fetiche, do qual um exemplo bastante comum é o pé. Um fetichista pode estar em posição de sádico, quando obriga o outro a realizar seu fetiche, ou de masoquista, quando se submete ao outro para obter seu fetiche.

Inicialmente imbuído de intenções pedagógicas e esclarecedoras, o discurso sobre o 
sadomasoquismo e o fetichismo ganha novas cores com o trabalho de campo. Observando as "cenas", conversando, escutando relatos e presenciando intrigas e fofocas entre as pessoas nas festas onde é praticado o BDSM, pude perceber um mundo de nuances, contradições, lacunas e áreas nubladas nas fronteiras de identidade comumente atribuídas nesse meio. O trabalho de campo veio então colorir as imagens que um certo "discurso oficial" sobre o sadomasoquismo parece engajado em disseminar.

Ressalto que minha contribuição não pretende "desmentir" ou "desmascarar" informantes, nem "revelar uma verdade oculta" sob esse discurso tão bem articulado que os praticantes de BDSM têm sobre si próprios. Aqui, trato de compartilhar um pouco desse colorido que a experiência de campo é capaz de proporcionar, adicionando texturas e relevo da minha própria experiência e evitando criar mais uma narrativa baseada nos estereótipos sobre o sadomasoquismo, tão espetacularizado na mídia e supersimplificado por uma certa tendência ao psicologismo.

Consideramos aqui o fato de que as categorias atributivas e identificadoras trabalhadas são empregadas pelos próprios atores e têm como característica organizar as interações entre as pessoas entre si e com as fronteiras extragrupos (Barth, 2000:27) e que ao lado dessas interações existem representações, crenças e valores que atualizam o que é ser BDSM e como é possível se encaixar nas categorias que o meio BDSM oferece para as estas pessoas.

\section{Mapeando o terreno}

Antes de começar a ir às festas, entrei em contato com Mrs. Nefer, a organizadora da festa FetiXe - que até então supunha ser a única festa BDSM acontecendo no Rio de Janeiro. Navegando livremente por páginas na Internet sobre o assunto, pude perceber que o próprio apelido que uma pessoa utiliza nos meios virtuais já traz a indicação do lugar que ocupa dentro das categorias nativas de identidade. Um dominador sempre recebe a designação de Mestre, Dom, Senhor. Uma dominadora é chamada de Rainha, Deusa, Senhora, Domme. Assim pude saber que, ao conversar com Mrs. Nefer, eu estaria conversando com uma dominadora. 
Doms e Dommes costumam usar e abusar das letras maiúsculas na hora de escrever sua alcunha. Aos submissos, servos e escravos, poucas palavras, em minúsculas e entre chaves \{\} ou colchetes [], simbolizando seu pertencimento ao dono, o que se chama “coleira virtual”. Por exemplo: Diogo ${ }^{1}$, escravo de Mrs. Nefer, pode assinar como "\{gattor\}- Mrs. Nefer".

Entretanto, sendo meu objeto uma festa, onde as pessoas não se apresentam com colchetes ou maiúsculas, os sinais nem sempre são claros. Há pistas. Existem escravos que são levados por coleiras de couro com guias de correntes por seus donos. Algumas dominadoras estão sempre com um chicote à mão. "Subs" (outra forma de chamar os submissos) costumam sentar-se no chão e andar com a cabeça baixa, ou em quatro apoios, quando estão sendo dominados. Na minha primeira observação em campo, por exemplo, logo no início da festa, uma jovem sub se sentou ao meu lado e, conversando com ela, descobri que meu colar bem rente ao pescoço dava a entender que eu era uma escrava - e com dono! Meu colar havia virado coleira. Tirei-o, discretamente, para não me encaixar em nenhuma categoria a priori.

Interessou-me perceber como eu seria abordada naquele ambiente não portando nenhuma destas marcas distintivas de posição de poder. As aproximações e abordagens são sempre um risco quando não é possível saber quem é o outro. Um dominador que se interessa por uma mulher sozinha dirige-se a ela com certa altivez, mas sem exagero, afinal, existe a possibilidade de ela ser também uma domme e se sentir ofendida com uma aproximação mais incisiva. Doms e dommes esperam que os potenciais subs e escravos os abordem de maneira humilde e servil. Para evitar enganos e gafes, muitos frequentadores levam bastante tempo observando uns aos outros, percebendo o que cada um faz, com quem conversam e se eventualmente se engajam em "cenas".

Aí entra um importante elemento de análise de meu trabalho de campo nas festas BDSM. Nessas festas - chamadas entre os praticantes de "play parties" - se desenrola um tipo de interação em que os lugares de poder são encenados em público. Não por acaso essas práticas chamam-se cenas, ou "plays". Num sentido goffmaniano, podemos considerar a perspectiva da representação teatral como forma de se estudar a vida social, considerando: 
(...) a maneira pela qual o indivíduo apresenta, em situações comuns de trabalho, a si mesmo e a suas atividades às outras pessoas, os meios pelos quais dirige e regula a impressão que formam a seu respeito e as coisas que pode ou não fazer, enquanto realiza seu desempenho diante delas (Goffman, 1975, p.7)

Este indivíduo, que nas festas encontra-se em cena, relaciona-se com outros atores sociais e com a plateia. O papel que cada um destes elementos representa está diretamente relacionado aos papéis do outro. Neste universo, reinam expectativas, antecipações, técnicas, estratégias e práticas de controle de si e das impressões.

As cenas ou plays constituem neste sentido uma definição de situação, ainda no sentido goffmaniano, pois permitem gerar informação sobre o indivíduo que as pratica. Os riscos de abordagem aos quais nos referíamos anteriormente podem ser minimizados quando uma pessoa tem a oportunidade de assistir a uma cena e conhecer a posição do outro naquele ambiente. As cenas recebem nomes dificilmente reconhecidos por quem não é do meio. Para citar alguns exemplos, há o wax play, spanking, inversão, privação, trampling, crushing, sissy, fisting, shibari. Nas festas, mesmo esses nomes são simplificados e metonimicamente já representam a própria cena. Assim uma pessoa pode "fazer uma vela" (participar de um "wax play") ou "fazer um pônei” ("poney play"). Em comum a todas elas, há o fato de serem pelo menos duas pessoas em posições assimétricas de poder, em que um manda/domina/submete e o outro obedece/é dominado/submete-se.

Pela via da observação e análise da situação, um iniciante pode mapear a cena e criar um roteiro de como agir, a quem se dirigir e como fazê-lo, tendo como expectativa relacionar-se numa posição de dominador ou submisso. Um "podo" - podólatra, fetichista apaixonado por pés - pode ficar observando longamente os pés de uma mulher, à distância, talvez pensando se deve ou não se aproximar, antes de partir efetivamente para a ação. Ou pode procurar uma cena em que uma mulher esteja tendo seus pés adorados, ou fazendo um trampling $^{3}$, e é muito comum que vários podos fiquem aglomerados em volta, educadamente esperando sua vez, já que uma rainha pode pisar e receber adoração de quantos podos desejar, inclusive mais de um ao mesmo tempo.

Os podólatras são uma categoria identitária diretamente vinculada ao fetichismo. Embora fetichismo e sadomasoquismo não sejam a mesma coisa, caminham juntos em 
vários discursos, inclusive o nativo: as chamadas play parties BDSM sempre incluem, no seu rol de práticas e cenas, o fetichismo. Para algumas pessoas, BDSM é um tipo de fetiche; poucos reconhecem a possibilidade de haver uma relação de dominação/submissão na podolatria, embora a maioria dos podólatras pratique alguma cena sub. Como seu fetiche são os pés, não é raro que os podos também gostem de ser pisados num trampling, por exemplo. Trata-se, ainda, de uma questão em aberto: seria a podolatria um tipo específico de submissão?

Esta pergunta aparece em virtude de uma conversa informal, quando conheci Senhora Fernanda na festa de Supremacia Feminina. Segundo a própria, ela é a "única domme podólatra". E, para explicar a exceção da regra, ela diz que só é podólatra com homens baunilhas; nunca adora pés de outras mulheres, apesar de achar bonito; e enfatiza que nunca, nunca adorará os pés de um podo, que para ela é "aleijado". Durante toda sua fala ficou marcada a importância do tesão que acontece numa cena de podolatria (e, sendo ela heterossexual, descartava cenas com outras mulheres) e da necessária assimetria das relações: podo não adora pés de podo.

Aqui entra uma primeira reflexão sobre a articulação entre prática e identidade que, mesmo não estando presente explicitamente no discurso nativo, aponta para um jogo de teorias e negociações sobre quem é quem no mundo BDSM para aqueles que o praticam. É possível ser podólatra e dominador? Sim, mas há que se negociar e fazer acordos que mantenham ambas as identidades sem que uma comprometa a outra. Senhora Fernanda inventou manobras criativas para lidar com a contradição teórica e com isso trouxe ao primeiro plano a questão da demarcação da diferença. Mesmo sendo uma exceção podo, não pode contornar este imperativo.

Nessa área de fronteiras borradas, soma-se aos podólatras mais uma categoria que confunde pessoas de dentro e de fora da cena: os switchers. Eles recebem esse nome porque, em inglês, to switch significa trocar, alternar, e é o que os switchers fazem: ora comportam-se como dominadores, ora como submissos.

Isso complica um pouco as coisas porque embora a cena seja de grande importância para nortear a ação na situação, ela não é suficiente para garantir identidade alguma: todos os atores estão sob constante suspeita de serem switchers. "A segurança que 
justificadamente sentem ao fazerem inferências a respeito do indivíduo variará, é claro, de acordo com fatores tais como a quantidade de informação que possuam a seu respeito" (Goffman, 1975, p.13). Como afirma o autor, na presença imediata dos outros não há como obter informações conclusivas a respeito dos atores. "Muitos fatos decisivos estão além do tempo e do lugar de interação, ou dissimulados nela" e só podem ser "verificadas indiretamente, através de confissões ou do que parece ser um comportamento expressivo involuntário”. (Goffman, 1975, p.12)

Como categoria incerta, os switchers não costumam ser vistos com bons olhos - são acusados de imaturidade por não terem descoberto ainda sua "essência", por estar "em cima do muro". Por isso, existem mais switchers do que se imagina, apesar de um certo segredo. A possibilidade switcher ronda o ambiente BDSM de forma muito mais ampla. Alguns se confessaram switchers pedindo confidencialidade (por exemplo, um informante que se apresenta nas festas como sub, mas teve vários relacionamentos em que atuou como dominador). Soube, pelo canal da fofoca, que várias rainhas da festa são submissas entre quatro paredes. Também pude presenciar, estando "por acaso" em locais específicos, rainhas apanhando num pequeno ambiente (estavam num grupo de amigas mais íntimas).

Um caso exemplar foi quando abordei meu primeiro switcher. Ele parecia receptivo, interessado em me conhecer, então me aproximei, perguntei seu nome, percebi que tinha um sotaque estrangeiro, quis saber de onde era - italiano. Depois desse prólogo, eu quis saber se ele era dom ou sub, uma pergunta que eu fazia em algum momento da conversa, quando a pessoa não informava antes. Ele parecia não entender minha pergunta. Repeti. Isso aconteceu mais duas vezes e então ele me devolveu a pergunta, ainda sem responder. Falei a verdade: "Sou baunilha". Só depois disso ele disse que era switcher. Então entendi: como bom switcher, ele não queria se limitar a ser dom ou sub. E, como é comum entre os switchers, não é em qualquer ocasião que se pode assumir essa identidade. Tenho quase certeza de que ele fingiu não entender minha pergunta a fim de ganhar tempo e descobrir o que eu era, para daí definir o que ele poderia ser em relação a mim. Imagino que, dependendo da minha resposta, ele não se declararia switcher.

Esses dois grupos distintos, podólatras e switcher, vêm mostrar que dominador e submisso não são categorias identitárias estanques e suficientes; ao mesmo tempo em que 
se referem a uma identidade em função de uma prática, referem-se ao que se deve praticar em função de uma identidade. Percebemos que estas variações e nuances, que confundem o tipo ideal do completo dominador ou do completo submisso, formam por si próprias novas categorias dentro do mundo BDSM, assim como ocorre com os desviantes em Becker (2008) ou as variações étnicas em Barth, quando este afirma que "as variações tendem efetivamente a se agrupar" (Barth, 2000, p.54):

Switchers e podos resistem à categorização com base em relações de poder, ou pelo menos as problematizam. Talvez por isto sejam vistos como poluidores, indefinidos ou "em cima do muro", principalmente os switchers, nos quais a oscilação do poder pode confundir mesmo os frequentadores mais antigos das festas, que perguntavam: "Ué, mas rainha apanha?".

\section{Condições de possibilidade}

Conversas informais e entrevistas durante e após as festas constantemente se referem ao BDSM como uma potencialidade que qualquer pessoa tem "desde que nasce", sugerindo algo da natureza da própria sexualidade que muitas vezes se encontra reprimido. As pessoas que não manifestam seus interesses por dominação ou submissão desde pequenas podem eventualmente "se descobrir" mais tarde, seja por ocasião de eventos sociais (contato com pessoas que pratiquem, visita a uma festa sadomasoquista/fetichista, realizando uma etnografia...), ou movimentos mais reflexivos (busca de informações, psicoterapia, busca de "liberação sexual”, de “apimentar” relacionamentos).

Dizer que "todo mundo tem seu fetiche" ou que "no fundo, todo mundo tende mais para um lado, dominador ou submisso" franqueia, democraticamente, qualquer indivíduo a entrar nas práticas sadomasoquistas. Mas alguns permanecem baunilhas, como são chamados os não-adeptos. Aqui falo de "permanecer baunilha" seguindo a lógica BDSM de que sempre é possível "evoluir" para o sadomasoquismo em algum momento da vida e os que não o fazem deixam de ganhar esse "a mais" e se contentam com uma normalidade, de prazer limitado, que é o mundo baunilha.

Aqui interessa perguntar como se dá essa "evolução". Os que não se contentam com o mundo baunilha e hoje estão no circuito de festas do Rio de Janeiro são alguns poucos 
eleitos que passaram por experiências cruciais das quais um importante marcador de pertencimento grupal é a iniciação. Marcel Mauss mostra como, no caminho de se tornar um mago, a iniciação põe o indivíduo em contato com uma tradição a partir de condições prévias de possibilidade: "Não é mágico quem quer: há qualidades que distinguem o mágico do comum dos homens. Umas são adquiridas, outras congênitas; há algumas que lhe são atribuídas, outras que ele possui efetivamente" (Mauss, 2003, p.64). Imediatamente me vem à mente um episódio em que Senhora Fernanda olha para meus pés descalços e diz que eu tenho "dedo de dominadora" (o segundo dedo do pé mais comprido do que o dedão). Essa característica seria um sinal de aptidão para a dominação, caso eu decidisse enveredar pelo BDSM. Então eu pergunto a ela se ela tem esse dedo de dominadora também, ao que ela nega, justificando-se: "Não é uma regra, cada um se descobre do jeito que é" (diário de campo de 07 de junho de 2009).

É interessante aproximar a trajetória do mágico e a de um adepto do BDSM. Que condições teve para ultrapassar os muros do mundo baunilha e se assumir publicamente em uma cena? Que qualidades acreditou ter, ou a ele foram atribuídas, que sustentassem a opção por uma participação naquele meio? Que caminho precisou percorrer para ser aceito como submisso e atuar nas cenas? O que poderia colocar sua credibilidade como dominador em risco? Como, no caso de oscilar entre as duas posições, de dominador e de submisso, conjugá-las sob a identidade de switcher? Como passou a se entender como podólatra?

Se, para muitos frequentadores, a primeira vez na festa teve valor de iniciação, o reconhecimento social imediato se dá por uma forma mais explícita, que é a participação em uma cena. Ela é fundamental para diferenciar-se dos meros observadores ou curiosos em geral e colocar em ato aquilo que antes estava apenas no mundo psíquico (através da fantasia), no mundo virtual (através de recursos de Internet), ou no mundo privado (para quem pratica o BDSM apenas entre quatro paredes). Deste modo, por mais que uma pessoa se acredite um sadomasoquista, é na participação junto àquela comunidade que esta identidade se atualiza e pode se confirmar.

Mauss aponta outros aspectos da iniciação do mágico que ilustram o que ocorre no processo de iniciação numa festa BDSM. Um primeiro aspecto é que a iniciação promove 
uma mudança de personalidade que se traduz por uma mudança de nome. Como já expusemos inicialmente, o novo nome é carregado de valor de identidade. Trago aqui um relato de campo sobre a primeira vez de um rapaz na festa e como se deu sua iniciação no meio:

À nossa frente estão Diogo e Ian, dois amigos que estão pela primeira vez na festa. Jeito de garotos, tímidos, conversam entre si, olham muito, parecem querer se aproximar. De maneira embaraçada, Diogo se aproxima para conversar. O amigo vem em seguida. Pedem licença; perguntam nosso nome e se apresentam com nomes "baunilhas" (geralmente as pessoas têm duas identidades, uma "baunilha" - nome verdadeiro, que não é revelado a qualquer um - e uma identidade BDSM, para acesso e participação na Internet e nos grupos, festas). Quando sugiro que peguem cadeiras para se sentar conosco, Ian vai pegar, mas Diogo se senta no tapete: 'No chão 'tá ótimo'. Identificam-se como podólatras. Diogo diz que eventualmente pode apreciar um trampling.(...) Fui embora à 1h30, porque era uma quinta-feira e eu já estava cansada, não conseguia mais conversar tão bem, minha pilha estava acabando. Diogo estava há um tempão sendo massacrado por uma dominadora elétrica, que não parava quieta em momento nenhum da festa. Sempre que eu olhava para ela, estava entretida maltratando alguém (às vezes mais de um). E Diogo, que chegou na festa como podólatra, saiu todo surrado: levou cera, chicote, sufocamento, trampling (inclusive nas partes genitais), tapa na cara, mais cera, mais chicote, mais trampling, soquinhos, socões, pés esfregados na cara e outras humilhações psicológicas e físicas (abaixar a cabeça, ficar de quatro, além de palavras que ela falava no ouvido dele, com cara de mandona, como se fossem ordens). Para quem veio a primeira vez, se apresentou como podólatra e eventualmente curtia trampling, digamos que ele ampliou muito seus horizontes! Fui embora sem conseguir saber quando Diogo parou de apanhar. (adaptado do relato de campo de 15 de maio de 2009).

Encontro o mesmo rapaz na festa seguinte, a Delirium, com o tema "Supremacia Feminina" (ou seja, sem lugar para cenas de homens dominando mulheres). Diogo chega logo no início da festa e conversamos. Ele então contou, muito feliz, que já era escravo de uma rainha (não aquela que o espancara na festa anterior) e que agora era conhecido como “Gattor". A partir de então, todas as cenas de que Diogo participava eram com sua rainha ou com uma outra rainha indicada por ela. Passou a festa inteira andando de quatro, apanhando, fazendo pônei ${ }^{4}$, pegando bebidas para sua rainha, ou simplesmente sentado como um cachorrinho a seus pés, de cabeça baixa. Nas festas seguintes ele já era conhecido por seu novo nome. Já se fala dele nas comunidades virtuais; também é reconhecido como 
um dos escravos mais resistentes. "Gattor", ao que tudo indica, teve uma iniciação bemsucedida.

Resistência e obediência são duas características importantes para um submisso. Raramente um sub consegue tornar-se escravo de uma rainha rapidamente; há um tempo necessário de adaptação, conhecimento, “adestramento", em que essas e outras características são colocadas à prova. Também é um momento em que ocorre, como bem mostrou Mauss na trajetória do mago, a transmissão de técnicas e receitas, segredos das práticas, que nunca são totalmente revelados antes que o potencial escravo prove-se merecedor.

Lord Terra, um dominador que conheci no mesmo dia que Diogo (e que só veio a me dizer seu nome baunilha depois), me contou que já se relacionou com várias mulheres submissas, mas agora está procurando uma escrava. Para isto, acredita ser necessário um período de experiência para "ver se realmente é submissa ou se apenas tem curiosidade ou busca apenas sexo selvagem ou coisa parecida". Nas palavras de Lord Terra, existe um treinamento, em que a escrava é "adestrada", já que uma sub teria ainda muitos “sentimentos baunilhas" e por isso seria inferior à escrava. Ele explica:

Lord Terra: A sub se entrega com limites, se algo não a agrada ela questiona, ela negocia com o seu Dono. Já a escrava não. Ela só obedece aos desejos e anseios do seu Senhor.

Imagina se uma mulher fala pra mim que quer ser sub, aí eu pego e meto o chicote nela. Aí ela não gosta, fica toda marcada, vai na delegacia e dá queixa de mim. Eu sou enquadrado na Lei Maria da Penha. Olha o problema.

Antes de entrar na relação se negocia. Isso é algo complexo. Pois uma escrava que eu conheço me disse que negociou com o dono dela que ele só teria ela como escrava. E eu lhe perguntei: 'isso não vai contra ser escrava, já que a escrava não tem desejos, só atende aos desejos do seu dono?'. Ela disse 'sim'. Entretanto colocou isso como condição para entrar na relação. E me disse, 'mas eu sei que se o meu dono com o passar do tempo arrumar uma outra escrava eu vou aceitar, mesmo não gostando, pois sou escrava. (conversa através do MSN, na Internet).

Na festa Delirium "Supremacia Feminina” fui apresentada à Rainha Lótus (embora o nome indique que seja uma dominadora, ela se diz switcher). Enquanto pisava no rosto de um rapaz novato na festa, explicou-me sua margem de negociação com o escravo. Por 
exemplo, quando um escravo não aceita determinada humilhação, ela consente em parar, mas ele deve ter uma "recompensa" depois - vai sofrer outro tipo de humilhação. "Se ele não for até a privada, pode lamber o chão, ou então eu jogo uma cerveja no chão para ele lamber" (diário de campo de 07 de junho de 2009).

O caminho para ser dominador também requer conhecimentos, observação, técnicas e formas específicas de apresentação de si. "Leo", que se apresenta nas festas como submisso (mas confessou-me ser switcher), diz que não acredita numa dominadora que não saiba transmitir seu poder através do olhar: "Não adianta pegar no chicote se não consegue sustentar o olhar" (diário de campo de 07 de junho de 2009). Outro switcher diz que quer ser dominado por uma mulher que o atraia, mas, para ele querer servir, a domme tem que saber dominar (diário de campo de 15 de maio de 2009). Mrs. Nefer observa os dominadores que aparecem na festa: “(...) Tem gente que já chega assim: 'Eu sou dominador', aí eu penso 'O cara chega aqui botando a maior banca. Eu aposto que em casa a mulher (risos) dá-lhe uns catiripapos'. Eu já conheço... (risos)" (entrevista de 28 de abril de 2009). Ela explica que dominação realmente não é para qualquer um.

Mrs. Nefer: Porque a voz de comando, a voz da pessoa, isso mexe muito. Não adianta você fazer uma cena, pá (faz o gesto de bater), pá, bater, não adianta. Você tem que chegar e ter voz de comando. Chegar no ouvido da pessoa: 'Tou te xingando porque você não vale nada', tem que ser uma voz de comando. Porque uma coisa muito difícil é a dominação psicológica. Você pode chegar com um chicote e pá, e falar: 'Faz isso', qualquer um faz, agora você, na persuasão, na tua autoridade, chegar: 'Tu é um merda, tu é um bicho, faz isso, porque aqui você não passa de um escravo, dum merda, você tem que limpar o chão com a língua', é mais difícil" (entrevista de 28 de abril de 2009).

A própria Rainha Lótus relembra, em meio a risadas junto com Quaquá (um podólatra), sua estreia num spanking mal-sucedido. "Quando comecei a ir nessas festas, achava que era vale-tudo". Então, se o sub pedia para bater, ela "descia a mão". Como havia praticado boxe tailandês, desferiu um violento soco em Quaquá, cujos lábios sangraram. "Foi um soco técnico", disse Rainha Lótus, e todos rimos. Naquele momento ela e Quaquá já haviam superado o ocorrido e podiam dar risadas juntos, mas ambos estão de acordo que aquilo era "coisa de principiante". Talvez fosse um soco perfeito para o boxe tailandês, mas não para uma prática sadomasoquista. 
Existe um saber-fazer com o corpo - e com o corpo do outro - que não é imediatamente transmitido, mas que faz parte do processo de tornar-se membro do grupo. Assim com o submisso deve ser humilde e obediente, também deve conhecer os limites de seu corpo, sua resistência, o que está preparado para suportar e como agir caso não suporte mais ou esteja em risco. Mutatis mutandi, o dominador não pode apenas ostentar uma postura altiva e poderosa, mas deve também saber manejar os instrumentos de tortura, conhecer as diferentes intensidades de dor que um mesmo objeto pode proporcionar e saber flagelar sem colocar seu sub/escravo em risco.

Esse processo de conhecimento, de pedagogia dos comportamentos, está exemplificado em Howard Becker (2008), a respeito da construção da carreira de um usuário de maconha, desde o momento em que uma pessoa está aberta a experimentar a droga até se tornar um usuário por prazer. As primeiras experiências costumam não ser bem-sucedidas até que se domine um conjunto de técnicas; em seguida, o usuário precisa aprender a perceber os efeitos de sua prática; por fim, precisa aprender a gostar desses efeitos. Ao longo do aprendizado, as interações sociais têm o importante papel na aquisição de novos conceitos através da constante redefinição da experiência. Em todas as etapas, o prazer deve estar presente, pois é ele que impulsionará o usuário na continuação do uso:

O prazer é introduzido pela definição favorável da experiência que uma pessoa adquire de outras. Sem isso, o uso não prosseguirá, porque a maconha não será, para o usuário, um objeto de que ele pode lançar mão para obter prazer. (...) A probabilidade de que tal redefinição ocorra depende do grau da interação do indivíduo com outros usuários (Becker, 2008, p.65)

Ao lado do aprendiz, a presença de um usuário mais velho costuma ser confortadora e também servir como um guia. Mrs. Nefer conta sobre o cuidado que tem com os principiantes em suas festas, quando querem participar de suas primeiras cenas:

Mrs. Nefer: Eu fico muito atenta. Se a mulher diz: 'Ah, eu sou dominadora, vou pegar o chicote', eu observo muito. Só na forma de pegar o chicote e começar a bater... Você não espanca, você bate para dar prazer. Então, quando ela chega tátátátá, isso não existe. (...) É um jogo. Primeiro você seduz pra depois você bater e mostrar teu poder. Primeiro você tem que seduzir. Pegar uma pessoa e bater, dar num homem na cara, ele vai te chamar de maluca ou vai chegar e partir pro troco. Agora, se você seduz num jogo, você conhece a pessoa e sabe o que ela quer. Existe 
o trampling,, que são as pessoas que gostam de ser pisadas. Eu já vi mulheres de 120 quilos pisarem num homem, pularem e não acontecer nada. E já vi pessoas magras pularem e quebrarem uma costela (entrevista de 28 de abril de 2009).

As artes técnicas, estratégias e práticas envolvidas nas cenas não são, portanto, secundárias, mas constitutivas das identidades no meio sadomasoquista, ilustrando como as coisas operam ali. O início de Rainha Lótus - a cena do soco em Quaquá - é um exemplo de como isto acontece.

Avaliando sua trajetória inicial no BDSM, Rainha Lótus a considera "hard” (mais forte do que os padrões sadomasoquistas) e sem limites. Percebemos que foi necessário um aprendizado que provocasse a mudança na percepção de si e "refinasse" sua violência para com os subs. Ela conta que nas primeiras cenas extravasava seu ódio pelos homens, herança das então recentes decepções amorosas. Com o tempo, ela passou a encarar as cenas como uma divertida brincadeira. É interessante notar, aqui, o processo de domesticação da violência, que muda de plano: do psíquico, da história do sujeito, para algo socialmente compartilhado, dentro das regras que esse grupo aceita e ao mesmo tempo impõe aos adeptos.

\section{Impressões de si}

Marcel Mauss aponta que o mágico se acredita um “eleito”. Do mesmo modo, há algo de especial, um "a mais" que os freqüentadores das festas se atribuem, que os diferencia dos "meros baunilhas". "Não é somente a opinião pública que trata os mágicos como formando uma classe especial; eles próprios consideram-se como tais. Embora sejam, como dissemos, indivíduos isolados, eles puderam, de fato, formar verdadeiras sociedades mágicas" (Mauss, 2003, p.80).

A maneira de se portar nas festas envolve solenidades e procedimentos complexos de acordo com o que se pratica e a quem se dirige (Goffman, 1976). Podemos considerar os atos que acontecem na cena como verdadeiros ritos: têm circunstâncias especiais, exigem aparatos específicos para determinados fins (por exemplo, o "tramplódromo",5 e a Cruz de Santo André ${ }^{6}$ ), são realizados em locais fechados e escuros, com um certo tipo de música (Mauss, 2003). 
Para sustentar o caráter de eleição, a regulação das impressões de si frente ao Outro assume grande relevância no meio BDSM - que é, além do mais, uma categoria de desvio em relação à sociedade "normal"/baunilha. Não basta ser sadomasoquista ou fetichista; é preciso mostrar que não é louco, pervertido, violento, criminoso, pedófilo, promíscuo. Não é à toa que estão cercados de regras que enfatizam sua distinção de outras categorias "poluidoras".

Constatamos que o mágico possui geralmente uma regra de vida, que é uma disciplina corporativa. Essa regra consiste às vezes na busca de qualidades morais, da pureza ritual, ou numa certa gravidade de atitude, com freqüência em muitas outras coisas; em suma, esses profissionais cuidam dos aspectos exteriores de sua profissão (Mauss, 2003, p.81).

A regra de ouro entre os praticantes e simpatizantes do BDSM é o SSC, sigla para São, Seguro e Consensual, ou seja: para praticar o BDSM é preciso que todos os envolvidos estejam em sã consciência do que fazem; não pode haver riscos à sua saúde ou à sua integridade física; e deve haver um acordo prévio em que sejam esclarecidos os limites de cada um dentro do que se propõem a praticar. De acordo com Bruno Zilli, em sua análise do discurso BDSM, a noção de consentimento é central para sua legitimação e distinção de comportamentos patológicos, quando comparado com as definições psiquiátricas:

Tanto entre leigos quanto entre especialistas, o consentimento é entendido como o exercício e expressão da vontade individual em participar de uma atividade sexual. É o principal critério de distinção entre uma forma de sexualidade sadia e a forma patológica, tradicionalmente denominada perversão sexual (Zilli, 2007, p.9).

De maneira parecida, Barth (2000), em seu trabalho sobre as fronteiras - teóricas e empíricas - entre grupos étnicos, coloca a questão da identidade como definida na relação com o outro, ou seja, pelos limites que determinado grupo constrói, em dado contexto, para se diferenciar de outro(s). E é porque a noção de identidade sempre caminha junto com a de diferenciação que não se pode definir a primeira por uma característica essencial - é relacional, conjuntural, não fixa e não completa.

Distinguir-se do outro é um recurso significativo para manutenção de uma identidade e de controle das impressões a seu respeito. Diversos autores nos mostram os 
efeitos de apresentar-se a partir do que não é. Um exemplo é a construção da identidade entre os jovens alemães da geração pós-guerra, cuja principal preocupação era diferenciarse da geração anterior e com isto livrar-se da poluição pela violência do passado (Elias, 1997).

Em Simmel, encontramos o modelo da triangulação. Tal como ocorre nos conflitos, duas categorias opostas lançam mão de um terceiro elemento como "termômetro" de outros valores de desvio (Simmel, 1964). De acordo com este modelo, temos:

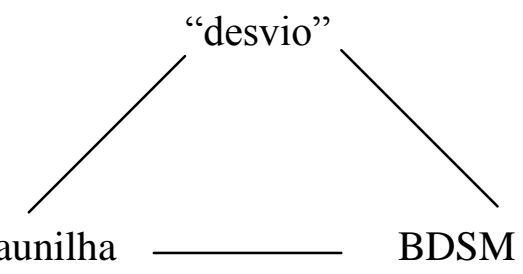

Onde como “desvio" temos categorias variadas, já citadas, das quais os praticantes de BDSM querem se desvencilhar: louco, pervertido, violento, criminoso, pedófilo, promíscuo. Alguns exemplos:

a) BDSM não são loucos.

Mrs. Nefer: Existe preconceito, né (...). Mas realmente existe uma falta de conhecimento e existe também um medo de se mostrar. (...) Eu conheci muitas pessoas que diziam 'ao invés de eu olhar pra bunda de uma mulher, eu olhava para os pés; eu achei que estava doente, que isso era maluquice minha'. (...) Porque, se todos os homens olham para a bunda, por que eu olho pro pé? Então, eu sou diferente, eu não vou falar com um amigo meu porque ele vai achar que eu sou doente (...). Então fica uma coisa assim muito escondida, quando na verdade, o BDSM, o fetiche, vamos colocar assim de uma forma geral, porque nem todo fetiche é BDSM, mas o BDSM é um fetiche, entendeu? Então o fetiche de uma forma geral eu acho que todo mundo tem" (entrevista no dia 28 de abril).

b) BDSM não são compulsivos, doentes.

Mrs. Nefer: A coisa se torna uma doença quando você faz daquilo o fator principal. Ele tem que disparar uma luz, mas quando ele começa a se tornar o fator principal, 'ai, eu quero um pé, eu quero um pé, eu quero um pé', isso se torna uma doença. Tudo o que é exagerado. Dizer: 'Eu não vou ter uma relação se a mulher não tiver os pés bonitos'. Acho que não tem nada a ver, o importante também ali é a pessoa, mas aí você tem que tomar um certo cuidado.

INTRATEXTOS, Rio de Janeiro, Número Especial 01, pp.65-84, 2010 
c) BDSM não é promiscuidade ${ }^{7}$.

Mrs. Nefer: Já aconteceram umas coisas muito engraçadas. Se você não botar um tipo de ordem, vai ficar uma grande bagunça. Não pelo pessoal BDSM, pelas pessoas que conhecem os fetiches, os praticantes. Eles não tão ali por sexo. A maioria fala: 'Sexo eu faço em casa, com a minha namorada'. Eles estão pela cena, aquele ritual, aquela liturgia. E justamente as pessoas baunilhas é que podem confundir.

Eu conheço o pessoal. E pra quem tá chegando pela primeira vez chega lá: 'Ah, eu fui na festa e aquilo lá é uma tremenda sacanagem, a mulher chegou lá e começou a pagar um boquete no cara'. Então eu digo: 'Olha, você pode bater, o cara pode estar nu, pode até morder. Bater no pau dele à vontade. Você só não pode botar a boca'. Não por mim.

Porque o homem baunilha em si... eles vão achar que tão indo num lugar em que a mulher é fácil e que tem uma estrutura boa sem gastar nada. Entrou, transou e tudo bem. Você não vai lá pra transar. Você vai lá pra participar de uma festa SM. Vai dançar, vai conversar, vai ter spank, trampling, vai fazer, ver podolatria, vai ver gente ser humilhada. Isso é importante, e não, transar. Isso excita as pessoas. (entrevista de 28 de abril de 2009).

Em relação ao mundo baunilha, a necessidade de distinção é ainda mais complexa. Por um lado, existe um discurso sobre a vantagem de ser BDSM - ligado, como já exemplificamos, à ideia de ser um universo mais livre, com pessoas mais informadas e menos reprimidas sexualmente. São especificidades que viabilizam um tipo de ganho cultural no desvio. Recorro, para ilustrar, ao relato da Senhora Fernanda em meu diário de campo:

'Senhora Fernanda' esconde dos relacionamentos baunilhas as idas às festas e sua prática de podolatria. Diz: 'Nunca aprovaram, tratam como 'coisa de vadia', acham que as festas são uma putaria, não conhecem, imaginam um monte de coisa, acham que a gente é suingueiro'. Como fica a vida afetiva?, pergunto. 'Limitada'. Para ela, os baunilhas não entendem. São menos abertos e confundem podolatria com 'liberalidade'. Aliás, começou a conversa falando que baunilha não sabe dar valor aos pés, acha sujo, feio, acha podolatria estranho, mas que para eles (podólatras) é um carinho especial, uma coisa muito gostosa, que tem que saber fazer e que baunilha não sabe. Frisou bastante a diferença entre baunilhas e podos. (diário de campo, 7 de junho)

Por outro lado, entretanto, percebemos que as categorias utilizadas como termômetro em relação ao mundo baunilha (não-loucos, não-pervertidos etc) são escolhidas 
dentro do repertório da própria sociedade estabelecida. Toda a preocupação do meio BDSM com a segurança e com o consentimento, traduzidos na regra do SSC, cria um discurso de uma sexualidade "politicamente correta" que parece minimizar os traços de desvio, ou pelo menos reduzir sua aparência de violência.

Em uma outra situação de desvio - o dia-a-dia dos moradores, especialmente os traficantes, de um bairro pobre de Nova York, estudada por Bourgois (1995) - o autor nos mostra como esta relação pode ser ambígua. Embora a cultura das ruas levante a bandeira da busca pelo respeito e pela dignidade frente à sociedade, também traz o potencial destrutivo contido nas atividades ilegais e violentas em que seus membros estão envolvidos. No caso do BDSM, vemos que o processo de legitimação e busca de respeito frente aos baunilhas não pode acontecer enquanto rondar a possibilidade da violência sem controle, da loucura, do abuso e da perversão.

Legitimidade interessa e, como diz Bourdieu, toda sociedade oferece a possibilidade de se obter um lucro do universal. Afinal, “(...) todas as coisas que os dominantes celebram, nas quais eles se celebram ao celebrá-las (...), só podem preencher sua função simbólica de legitimação que, justamente, beneficiam-se, em princípio, de um reconhecimento universal (...)" e assim asseguram "um lucro simbólico (principalmente de conformismo e de distinção) que, ainda que não seja buscado como tal, basta para lhes dar um fundamento sociológico e, ao lhes dar uma razão de ser, lhes assegura uma probabilidade razoável de existência” (Bourdieu, 1996, p.155).

Do mesmo modo que o discurso sadomasoquista/fetichista se aproxima de valores baunilhas para se legitimar, o caminho inverso também ocorre, através da mídia e da moda, como aponta Bourgois: "Ironically, mainstream society through fashion, music, film, and television eventually recuperates and commercializes many of these oppositional street styles, recycling them as pop culture"8 (Bourgois, 1995, p.8). Não é preciso nos estender em exemplos de referências sadomasoquistas/fetichistas na mídia, através de personagens como "Tiazinha", na moda de espartilhos, nos shows da cantora Madonna, na presença garantida de chicotes e algemas em sex-shops para todos os públicos ${ }^{9}$. 


\section{Palavras finais}

Ser BDSM é cumprir com muitas responsabilidades. Pertencer ao grupo, manipular as impressões de si e manter a reputação são obrigações impostas em nome da coesão social e nada disso seria possível sem um mínimo compromisso moral-afetivo.

Eu me percebi misturada aos valores nativos quando senti uma enorme antipatia por um podólatra em uma das festas. Eu já havia reparado que ele era muito altivo com as mulheres, o que não caberia bem numa festa cujo tema era "Supremacia feminina". Logo no início da festa, ele apanhou de chicote de uma rainha; encerrada a cena, pude ouvi-lo comentando - alto - que aquele chicote de couro "nem dói muito", que no fím das contas "ela que cansou o braço". Ele falava num tom tão insolente que eu me peguei pensando que aquilo não era uma atitude correta para um sub! Quando o abordei, mais perto do final da festa, ele me rotulou de "repórter" e disse que só daria um depoimento para minha "matéria" se eu fizesse um trampling nele. Não adiantou eu explicar que não estava escrevendo matéria nenhuma e que não faria o trampling. Ele não escutava nada enquanto eu não lhe desse o que queria. Fiquei sem um depoimento e com a impressão de que havia nele petulância demais, visto que era uma pessoa disposta a venerar as mulheres e se submeter a elas... foi quando pensei: não sou rainha.

\footnotetext{
${ }^{1}$ Alguns nomes e apelidos foram alterados para preservar a identidade dos informantes.

2 Play party: em inglês, significa algo como "festa para brincar/jogar/encenar". Entre os praticantes de BDSM, se refere às festas em que se desenrolam as cenas. $\mathrm{O}$ que pode ou não ser posto em ação é relativo e negociável, mas sempre relacionado ao sadomasoquismo ou fetichismo.

${ }^{3}$ Prática de pisar ou caminhar, descalça ou calçada, sobre o corpo do submisso/escravo. Pode chegar a graus dolorosos com o uso de saltos muito finos ou com a ação sobre áreas sensíveis como os genitais, rosto ou pescoço.

4 "Fazer pônei" ou poney play: o submisso anda de quatro levando a dominadora em suas costas como se fosse seu cavalinho.

${ }^{5}$ Como sugere o nome, é um local adequado para o trampling. Geralmente oferece apoio para as rainhas se equilibrarem enquanto pisam nos submissos, às vezes são forrados com tapetes e têm almofadas para apoiar a cabeça.

${ }^{6}$ Instrumento de tortura em formato de $\mathrm{X}$ em que o escravo fica preso pelos pés e punhos, com as pernas e braços abertos.

${ }^{7}$ Em relação à promiscuidade, há um alerta constante em relação à poluição por parte dos baunilhas na festa. $\mathrm{O}$ caso citado ilustra o receio que os praticantes do BDSM possuem de serem confundidos com tarados e atraírem pessoas em busca de sexo fácil ou sexo explícito. Isto se deveria, segundo os praticantes, à incapacidade de alguns baunilhas de entenderem o espírito da festa. A demarcação de fronteiras com os "suingueiros" (adeptos do swing) também aparece em várias falas.
}

INTRATEXTOS, Rio de Janeiro, Número Especial 01, pp.65-84, 2010 
8 “Ironicamente, a sociedade dominante, através da moda, música, filmes e televisão, volta e meia recupera e comercializa muitos destes estilos 'do contra' das ruas, reciclando-os como cultura 'pop"' (trad. livre).

${ }^{9} \mathrm{~A}$ esse respeito existe o artigo de M. F. Gregori (2004), que já aponta para a publicização do sadomasoquismo nas sex-shops em São Francisco, Estados Unidos, bem como a "naturalização" da associação entre erotismo e poder através da idéia de que o jogo de poder é central na fantasia.

\section{REFERÊNCIAS BIBLIOGRÁFICAS}

BARTH, Fredrik. O Guru, o Iniciador e outras variações antropológicas. Rio de Janeiro: ContraCapa, 2000.

BECKER, Howard. Ousiders: Estudos de Sociologia do desvio. Rio de Janeiro: Zahar, 2008.

BOURDIEU, Pierre. É possível um ato desinteressado?. In: Razões Práticas: Sobre a teoria da ação. Campinas: Papirus, 1996.

BOURGOIS, Philippe. In Search of Respect: Selling crack in El Barrio. Cambridge: Cambridge University Press, 1995.

ELIAS, Norbert. Terrorismo na República Federal da Alemanha - expressão de um conflito social entre gerações. In: Os Alemães: A luta pelo poder e a evolução do habitus nos séculos XIX e XX. Rio de Janeiro, Jorge Zahar Editor, 1997.

GOFFMAN, Erving. A representação do eu na vida cotidiana. Petrópolis: Vozes, 1975.

. The nature of deference and demeanor. In: Selected Papers from the American Anthropologist, 1946-1970. Washington: American Anthropological Association, 1976.

GREGORI, M. F. Prazer e perigo: notas sobre feminismo, sex-shops e S/M. In: GREGORI, M. F.; PISCITELli, A.; CARRARA, S. (Org.) Sexualidade e saberes: convenções e fronteiras. Rio de Janeiro: Garamond Universitária, 2004. p.235-255.

MAUSS, Marcel. Esboço de uma teoria geral da magia. In: Sociologia e Antropologia. São Paulo: Cosac-Naify, 2008.

SIMMEL, Georg. Conflict. In: Conflict and the Web of Group Affiliations. NY/London: The Free Press/MacMillan Publishers, 1964. 